\title{
Achene wall anatomy and surface sculpturing of Launaea Cass. (Compositae: Cichorieae) with notes on their systematic significance
}

\author{
Momen Mustafa Zareh, Ahmed Mohamed Faried ${ }^{1 *}$ and Mona Hassan Mohamed $^{1}$ \\ Biology Department, Faculty of Applied Science, Umm Al-Qurra University, Makkah, Saudi Arabia \\ ${ }^{1}$ Botany \& Microbiology Department, Faculty of Science, Assiut University, Assiut, Egypt \\ (Received 11 April 2016; Revised 28 May 2016; Accepted 27 June 2016)
}

\begin{abstract}
This is the first study to deal in-depth with the achene ultra-structure of the genus Launaea Cass. in Egypt. It focuses on 12 taxa belonging to 10 species of this genus. The achene wall anatomy and surface sculpturing of those taxa were studied using scanning electron microscopy (SEM). Important aspects of the investigated taxa based on the achene characters as well as SEM micrographs of the achene surface and anatomical sections are given. Main and secondary costa of the inner achenes are used for easy differentiation between L. intybacea and L. massauensis
\end{abstract}

Keywords: Launaea, achene, SEM, taxonomy, morphology, anatomy

The taxonomy of the genus Launaea Cass. has always been problematic due to its confusing taxonomic history. This is reflected in the number of species that have been described. Launaea consists of 55 species and is mainly distributed in the S. Mediterranean area and in Africa and S.W. Asia (Kilian, 1997). In Egypt, Launaea is the largest genus (by 10 species) of the tribe Cichorieae (Zareh, 2005). Forsskål and Niebuhr (1775) recorded L. spinosa (Forssk.) Sch. Bip. ex Kuntze and L. mucronata (Forssk.) Muschl.; Boissier (1875) reported 10 taxa for the flora of Egypt, viz. L. spinosa, L. mudicaulis (L.) Hook. F., $L$. massauensis (Fresen.) Sch. Bip. ex Kuntze, L. procumbens (Roxb.) Ramayya \& Rajagopal, L. capitate (Spreng.) Dandy, L. angustifolia subsp. arabica (Boiss.) N. Kilian, L. fragilis (Asso) Pau subsp. fragilis, L. fragilis (Asso) Pau subsp. tenuiloba (Boiss.) Zareh \& Mohamed, L. mucronata (Forssk.) Muschl. and L. cassiniana (Jaub. \& Spach) Kuntze. Muschler (1912) added $L$. fragilis and L. arabica (Boiss.) H. Lindb.. Amin (1957) in her thesis sited L. intybacea (Jacq.) Beauverd from Egypt, and finally Kilian (1997) reported L. amal-amine N. Kilian from Suez and Sinai. Recently, the genus has been subdivided in four sections, i.e., sect. Acanthosonchus (Sch. Bip.) O. Hoffm. (L. spinosa and L. acanthodes), sect. Microrhynchus (Less.) O. Hoffm. ( $L$. nudicaulis, $L$. intybacea and L. massauensis), sect. Launaea ( $L$. capitata) and sect. Zollikoferia (Pomel) O. Hoffm. (L. angustifolia,
L. fragilis, L. mucronata and L. cassiniana) (Kilian, 1997).

Flowers in Launaea are yellowish with pubescent corolla tubes. Achenes brownish, blackish, or grayish; it may be homomorphic with 5 main ribs, accompanied by 2 secondary ribs (rarely undistinguished) or heteromorphic with inner achenes 4-main ribbed and marginal achenes 5-main ribbed. It also has pappus white, persistent or deciduous, homomorphic with setaceous rays or dimorphic with downy outer and setaceous inner rays.

Carpological characters enable most Cichorieae species to be identified even when no flowers are present (Blanca and Guardia, 1997). Other suitable applications include the identification of herbarium specimens in which the thickness of the peduncle may have been exaggerated by over-pressing, or specimens with an unusual number of bracts for the species of concern (Blanca and Guardia, 1997).

The term achene was defined by Wagenitz (1976) as a dry type of indehiscent monospermatous fruit derived from an inferior ovary. Achene features have been successfully used for the taxonomic classification of a wide range of Compositae groups (Lavialle, 1912; Briquet, 1916, 1930; Dittrich, 1968; Grau, 1980; Mouradian, 1995; Dittrich, 1996; Jan and Mukherjee, 2012; Zareh et al., 2016; Zareh, 1987). They have also been used for a number of different taxonomic levels for the tribe Lactuceae (Ownbey, 1950; Stebbins, 1953;

\footnotetext{
*Author for correspondence: Faried55@yahoo.com
} 
Richardson, 1976; Tomb, 1977; De la Guardia and Blanca, 1987; Blanca and Guardia, 1997; Jan and Mukherjee, 2013).

In Launaea, the achenes morphology exhibits great diversity, and, as in the entire tribe, provides the most useful features for classification (Kilian, 1997). Appropriate descriptions of certain aspects of the achene morphology in Launaea, however, are rare in the literature, particularly concerning achene ribbing patterns. In the cross-sections of achenes, such deviations can be observed much more clearly (Kilian, 1997).

Anatomical sections of the achene were first employed by Lavialle (1912), who studied nearly 83 species of 15 genera of Compositae. Briquet (1916) studied the achene anatomy of the complexes Chrysanthemum and Anthemis. Achene anatomy studies have proved to be very rewarding to delimit the various taxa (Dittrich, 1968; Merxmuller and Grau, 1977; Haque and Godward, 1984; Mateu and Guemes, 1993; Abid and Qaiser, 2002; Zhu et al., 2006; Abid and Qaiser, 2008; Zareh, 1987). The most recent contribution to the knowledge on achenes anatomy in Launaea was provided by Kilian (1997), who studied the achene anatomies of representatives of all sections, only five species of which are represented in this study.

Studies on achene anatomies will be carried out to determine the strength of the systematic position of 12 taxa in the genus Launaea from Egypt. The major achene characteristics, including testa's epidermis pattern, are described in detail.

\section{Materials and Methods}

The plants used in achene studies were L. spinosa, $L$. acanthodes (Boiss.) Kuntze, L. nudicaulis, L. intybacea (Jacq.) Beauverd, L. massauensis, L. capitata, L. angustifolia subsp. angustifolia, L. angustifolia subsp. arabica, L. fragilis subsp. fragilis, $L$. fragilis subsp. tenuiloba, L. mucronata and $L$. cassiniana (Table 1).

Dry achene materials for SEM were prepared by mounting them directly onto clean stubs using double-sided adhesive tape, followed by coating with gold in a JEOL JFC $1100 \mathrm{E}$ ion-sputtering device and then an examination using a JEOL JSM $5400 \mathrm{LV}$ scanning electron microscope operated in an accelerated mode. The terms of Stearn (1966), Stant (1973), Barthlott (1981) and Boesewinkel and Bouman (1984) were used to describe the achene coat characteristics.

For the achene anatomy, dry achenes were boiled in water and then sectioned at 10-15 $\mu$ after being embedded in paraffin wax using a method described by Johansen (1940). The sections were stained using safranin ( $2 \%$ in $50 \%$ ethanol) and light green ( $1 \%$ in $95 \%$ ethanol). They then then permanently mounted in Canada Balsam.

The terminology of the achene wall anatomy essentially follows Lavialle (1912), Esau (1977), Kaul and Singh (1982) and Pak et al. (2001). The applied abbreviations to denote the details of the different layers of the achenes are as follows: e: epidermis, pm: primary mid rib, sm: secondary mid rib, par: parenchyma, scl: sclerenchyma, vb: vascular bundle, ec: endocarp, and sc: seed coat.

\section{Results and Discussion}

The achene of Launaea were brownish, blackish, or grayish; cylindrical to columnar; compressed or not, 2.5-8.0 $\times 0.4-$ $2.0 \mathrm{~mm}$; subterete or prismatic; apex truncate, cuneate or attenuate; base truncate, tubular or horned; glabrous or

Table 1. Voucher information for morphological examination of Launaea species in Egypt.

\begin{tabular}{|c|c|}
\hline Taxon & Voucher information \\
\hline L. spinosa (Forssk.) Sch. Bip. ex Kuntze & El Tur, 13.Jan.1930, EL-Hefnawi s.n. (CAIM) \\
\hline L. acanthodes (Boiss.) Kuntze & Wadi Telah, 7.Oct.1983, Fayed \& Zareh s.n. (ASTU) \\
\hline L. nudicaulis (L.) Hook. F. & Wadi Hagol, 13.April.2010, Zareh \& Aboul-Ela s.n. (ASTU) \\
\hline L. intybacea (Jacq.) Beauverd & Wadi Laseitit, 7.Feb.1962, Täckholm et al. 1687 (CAI) \\
\hline L. massauensis (Fresen.) Sch. Bip. ex Kuntze & Wadi Abu Ghusun, 7.March.1989, Zareh \& Fargali s.n. (ASTU) \\
\hline L. capitata (Spreng.) Dandy & AL-Oimed, 5.April.2012, Zareh \& Aboul-Ela s.n. (ASTU) \\
\hline L. angustifolia (Desf.) Kuntze subsp. angustifolia & Alamein Alexandria road, 10.April.2010, Zareh \& Aboul-Ela s.n. (ASTU) \\
\hline L. angustifolia subsp. arabica (Boiss.) N. Kilian & Siwa, 29.Dec.1969, Zahran s.n. (CAI) \\
\hline L. fragilis (Asso) Pau subsp. fragilis & Sidi Abdel Rahman, 4.April.2012, Zareh \& Aboul-Ela s.n. (ASTU) \\
\hline L. fragilis subsp. tenuiloba (Boiss.) Zareh \& Mohamed & Alexandria-Matrouh, K. 137, 4.April.2012, Zareh \& Aboul-Ela s.n. (ASTU) \\
\hline L. mucronata (Forssk.) Muschl. & Wadi Hagol, 13.April.2010, Zareh \& Aboul-Ela s.n. (ASTU) \\
\hline L. cassiniana (Jaub. \& Spach) Kuntze & Mersa Alam-Abu Ghusun road, 8.March.1989, Zareh \& Faraghali s.n. (ASTU) \\
\hline
\end{tabular}




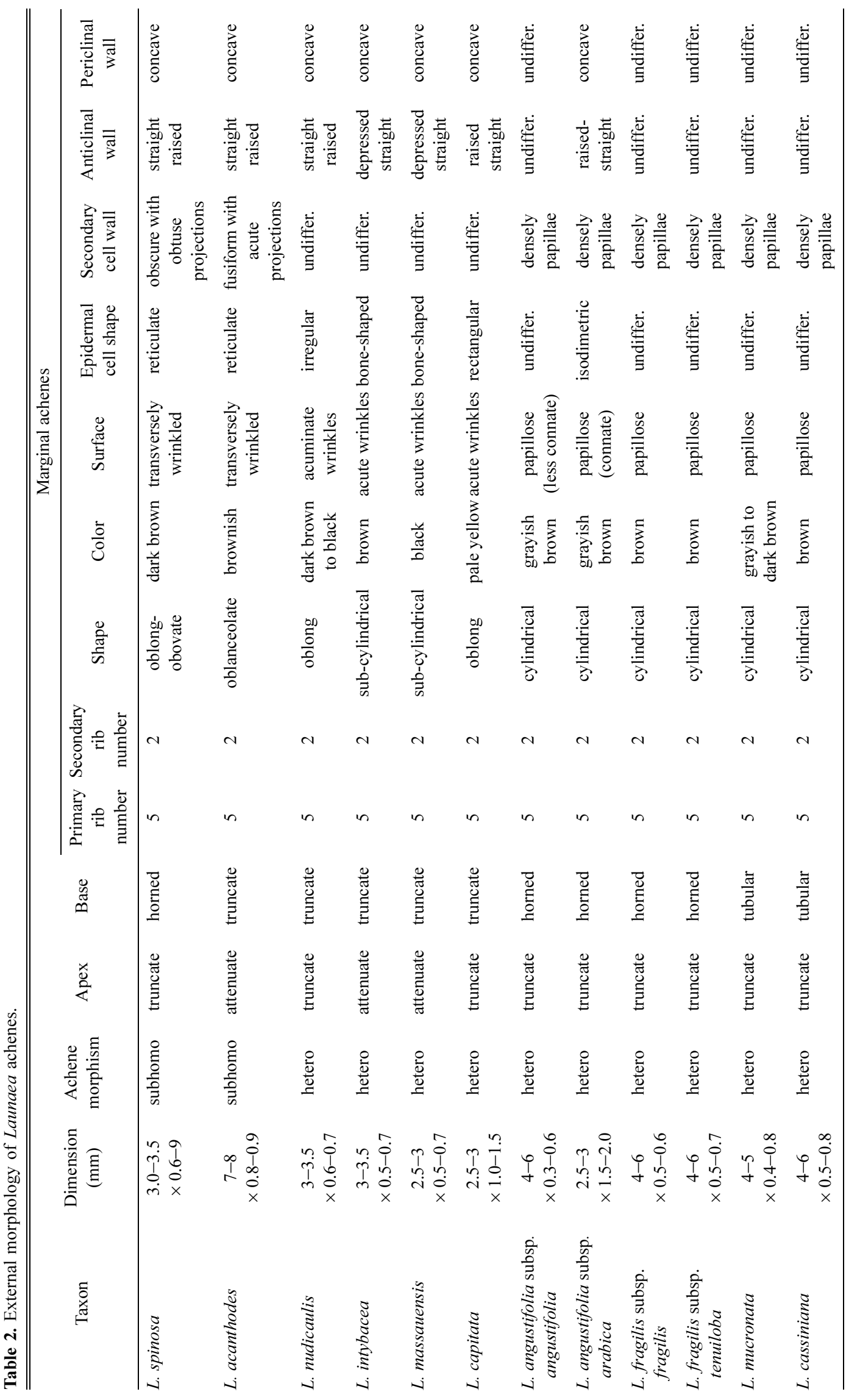




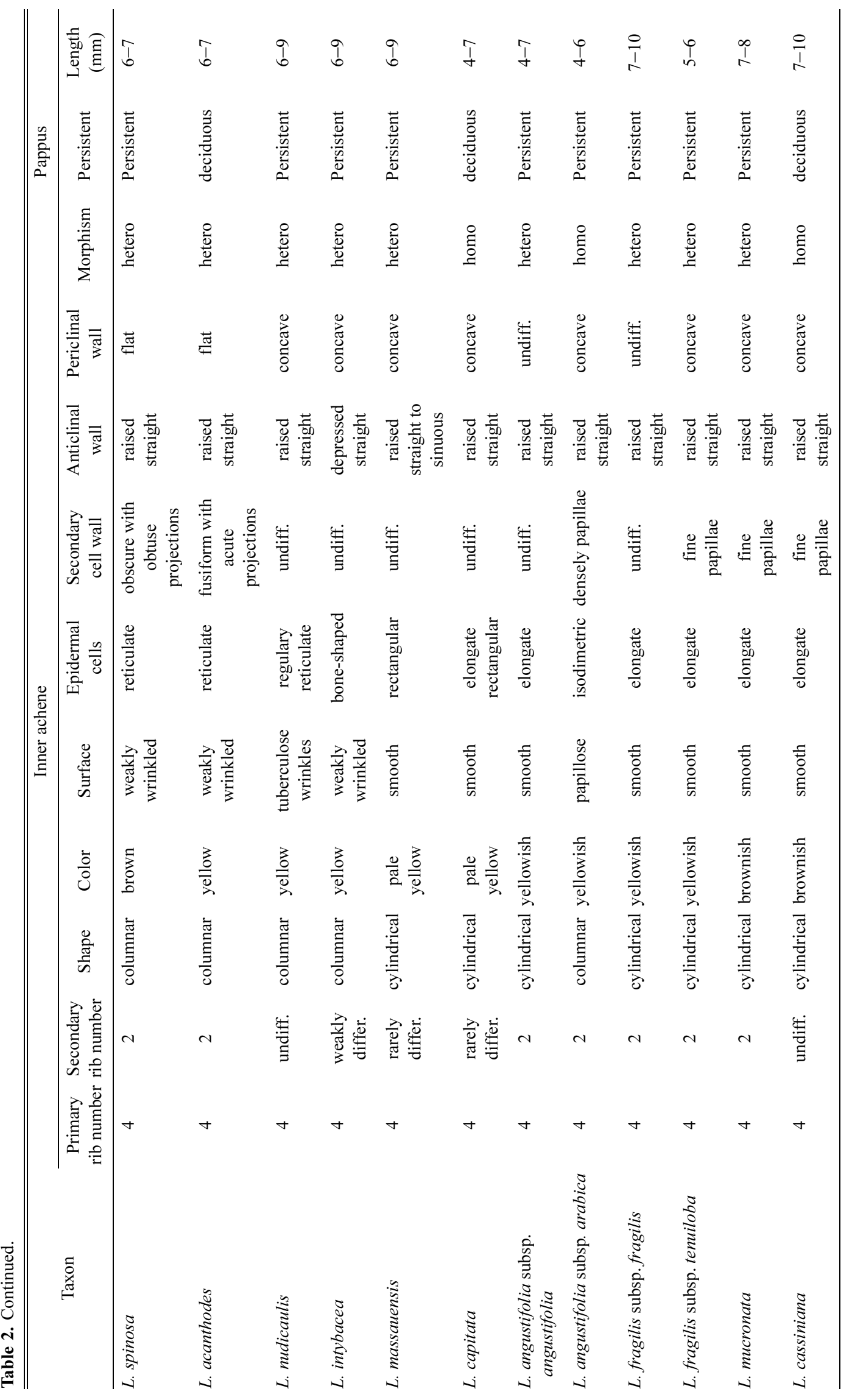


papillose; homomorphic with 5 main ribs, accompanied by 2 secondary ribs (rarely undistinguished) or heteromorphic with inner achenes 4-main ribbed and marginal achenes 5-main ribbed, ribs smooth or transversely wrinkled; epidermal cells reticulate, bone-shaped or undifferentiated with straight raised or depressed anticlinal walls and concave periclinal walls, secondary cell wall rarely obscure in outlines with obtuse projections. Pappus was white, persistent or deciduous, homomorphic with setaceous rays or dimorphic with downy outer and setaceous inner rays. The morphological criteria of the achenes are summarized in Table 2.

Anatomically, pericarp was thick, laterally compressed; 45 stranded, each strand composed of a large main costa accompanied with 2 slightly smaller secondary costae; main and secondary costae separated and slightly or clearly differentiated in size; exocarp composed of a single epidermal layer; mesocarp of main and secondary costae with 2-25 layers of parenchyma and 3-18 layers of sclerenchyma cells,

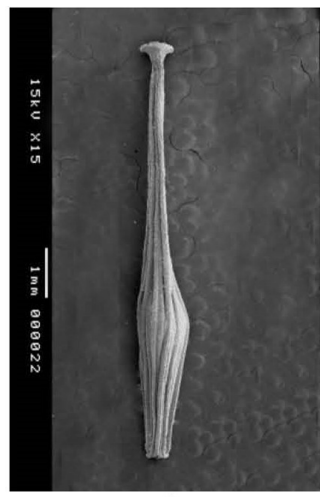

A

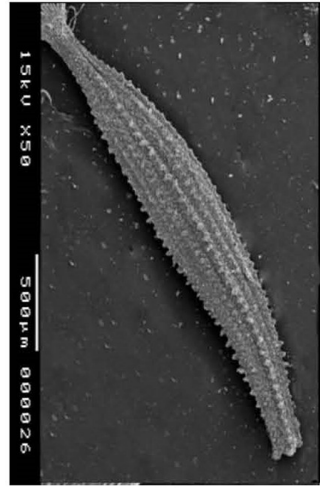

$\mathrm{E}$

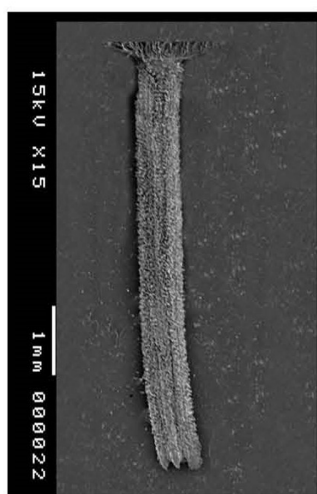

I

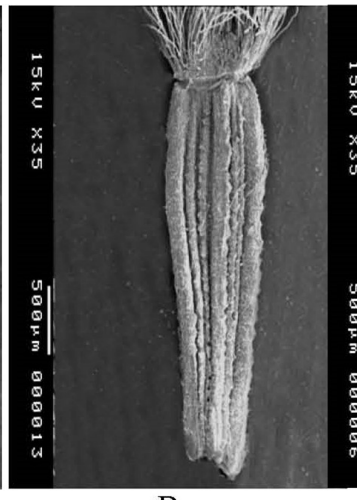

B

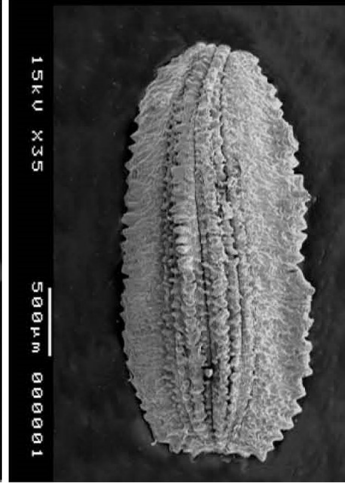

$\mathrm{F}$

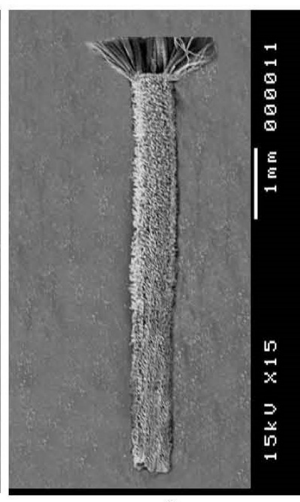

$\mathrm{J}$

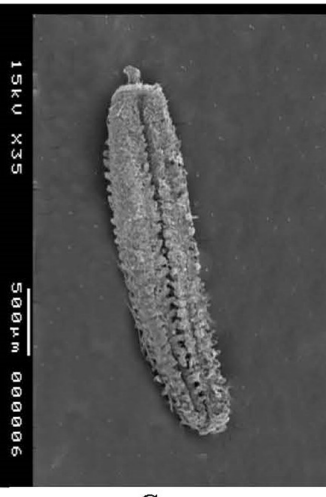

C

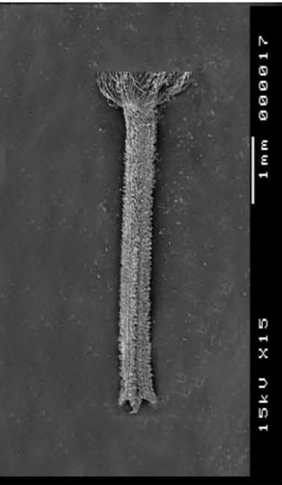

G

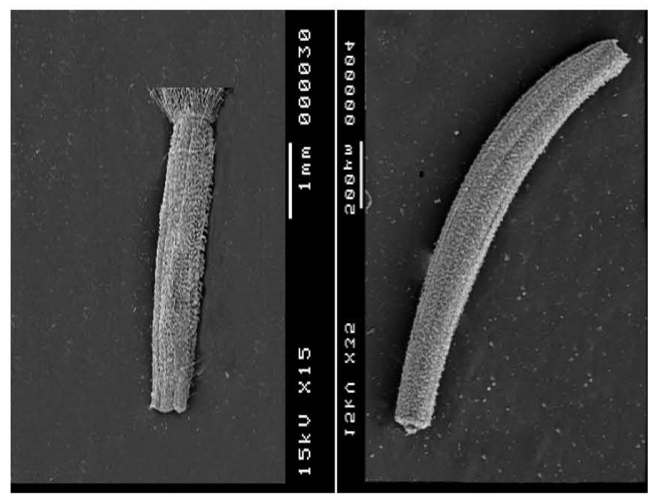

K

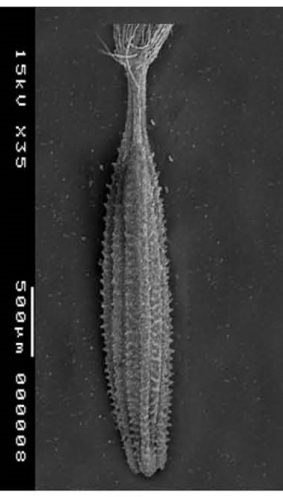

D

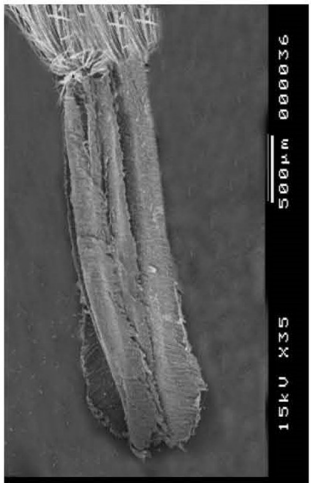

$\mathrm{H}$

Fig. 1. Scanning electron micrograph of marginal Launaea achenes. A. L. acanthodes. B. L. spinosa. C. L. nudicaulis. D. L. intybacea. E. L. massauensis. F. L. capitata. G. L. angustifolia subsp. angustifolia. H. L. angustifolia subsp. arabica. I. L. fragilis subsp. fragilis. J. L. fragilis subsp. tenuiloba. K. L. mucronata. L. L. cassiniana. 
additional smallish groups of sclerenchymatous cells between main and secondary costae may present; each main costae is corresponding with a vascular bundle; endocarp composed of one layer of parenchyma. The anatomical criteria of the achenes are summarized in Table 3.

The mature achenes of Launaea exhibit great diversity and have proved to be the most useful characters for the distinction of some of the studied taxa. This diversity appears in the shape, size, colour, apex, base, epidermal cells and indumentum. The achenes of the studied taxa are commonly heteromorphic except for the two species of sect. Acanthosonchus (L. spinosa and $L$. acanthodes), which are subhomomorphic. The studied achenes are commonly \pm cylindrical (oblong, oblanceolate or cuneate); only L. capitata and L. angustifolia exhibit winged achenes (Figs. 1, 2). Furthermore, the achene colour proved to be of a good taxonomic value, with most of the investigated marginal achenes being brown in colour, except for both $L$. capitata, which exhibits pale yellow achenes, and $L$.

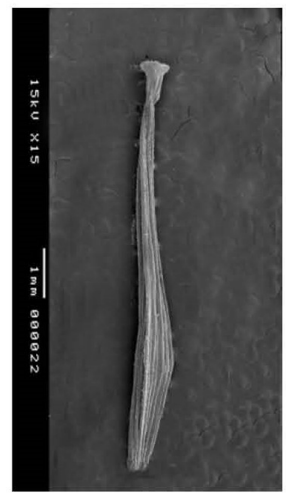

A

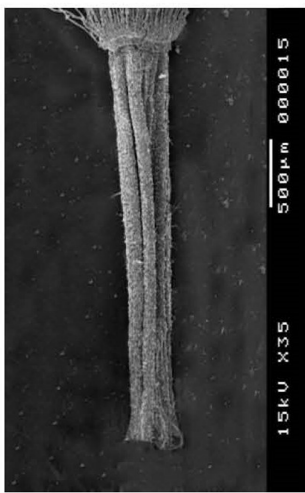

B

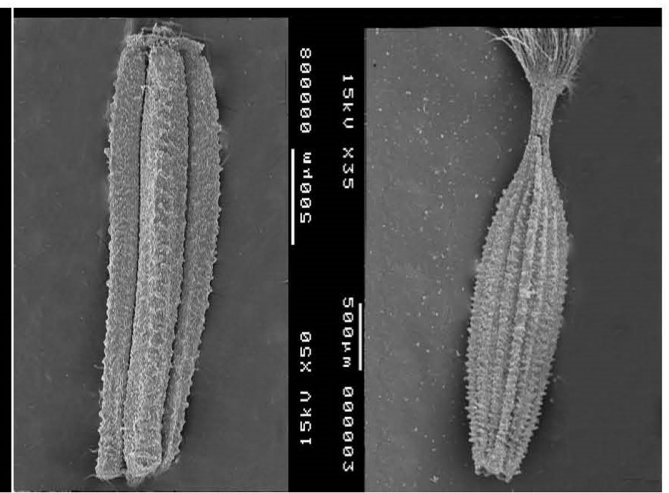

C

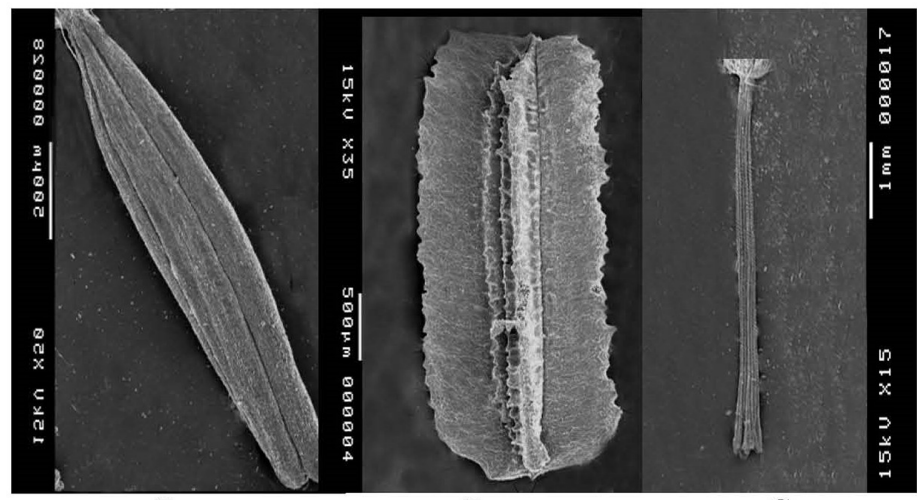

E
F

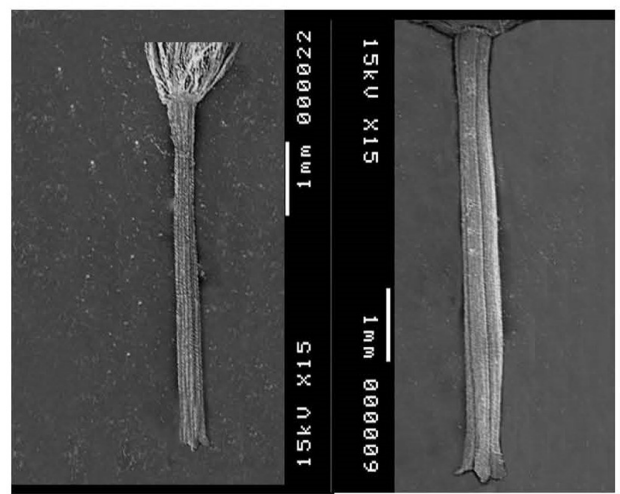

I

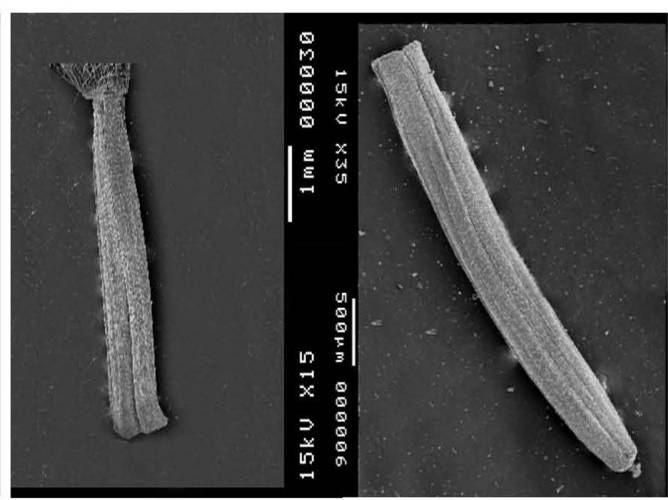

K

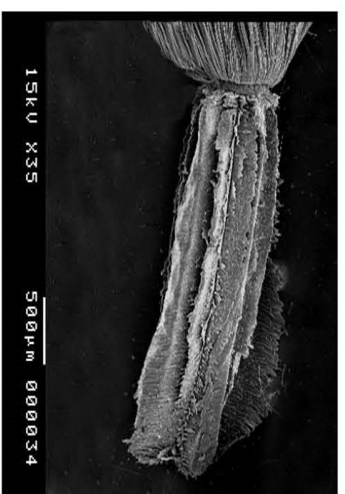

$\mathrm{H}$

Fig. 2. Scanning electron micrograph of inner Launaea achenes. A. L. acanthodes. B. L. spinosa. C. L. nudicaulis. D. L. intybacea. E. L. massauensis. F. L. capitata. G. L. angustifolia subsp. angustifolia. H. L. angustifolia subsp. arabica. I. L. frailis subsp. fragilis. J. L. fragilis subsp. tenuiloba. K. L. mucronata. L. L. cassiniana. 
massauensis, with black achenes.

Most of the examined achenes have an approximate size of $2-6 \times 0.5-1.3 \mathrm{~mm}$ (including the beak if present); in $L$. massauensis and $L$. procumbens, the achenes are apparently small, being $2-3 \times 0.5-0.7 \mathrm{~mm}$ in size, while in $L$. acanthodes and $L$. capitata, the achenes are large at $4-8 \times 0.9-1.3 \mathrm{~mm}$.

The achene apex of the investigated taxa was found to be truncate, except for three species (L. acanthodes, L. intybacea and L. massauensis) which are characterized by an attenuate apex. In addition, the achene base proved to be tubular in two species ( $L$. mucronata and $L$. cassiniana), horned in three species (L. spinosa, L. angustifolia and L. fragilis) and truncate in the remaining five species. Nevertheless, the achenes of the studied species are commonly wrinkled except for the species of sect. Zollikoferia (L. amal-aminae, L. angustifolia, $L$. fragilis, $L$. mucronata and $L$. cassiniana), which are characterized by papillose marginal achenes and wrinkled or smooth inner achenes (Figs. 3, 4).

Within the differentiated epidermal cells of marginal achenes, the anticlinal boundaries are generally undifferentiated in the

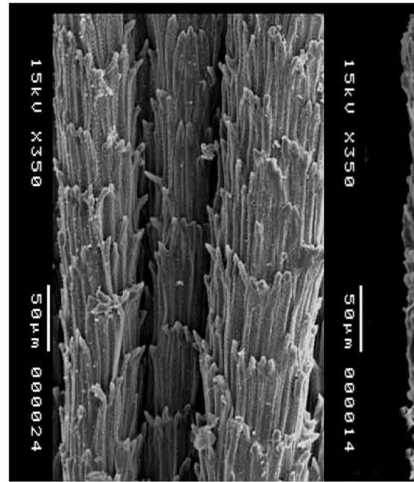

A

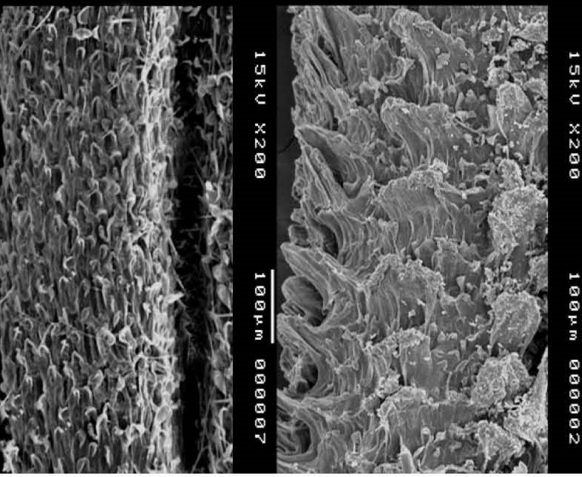

C

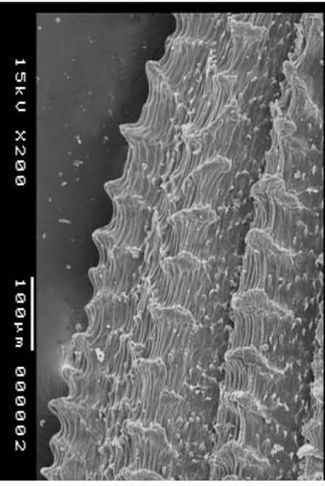

D
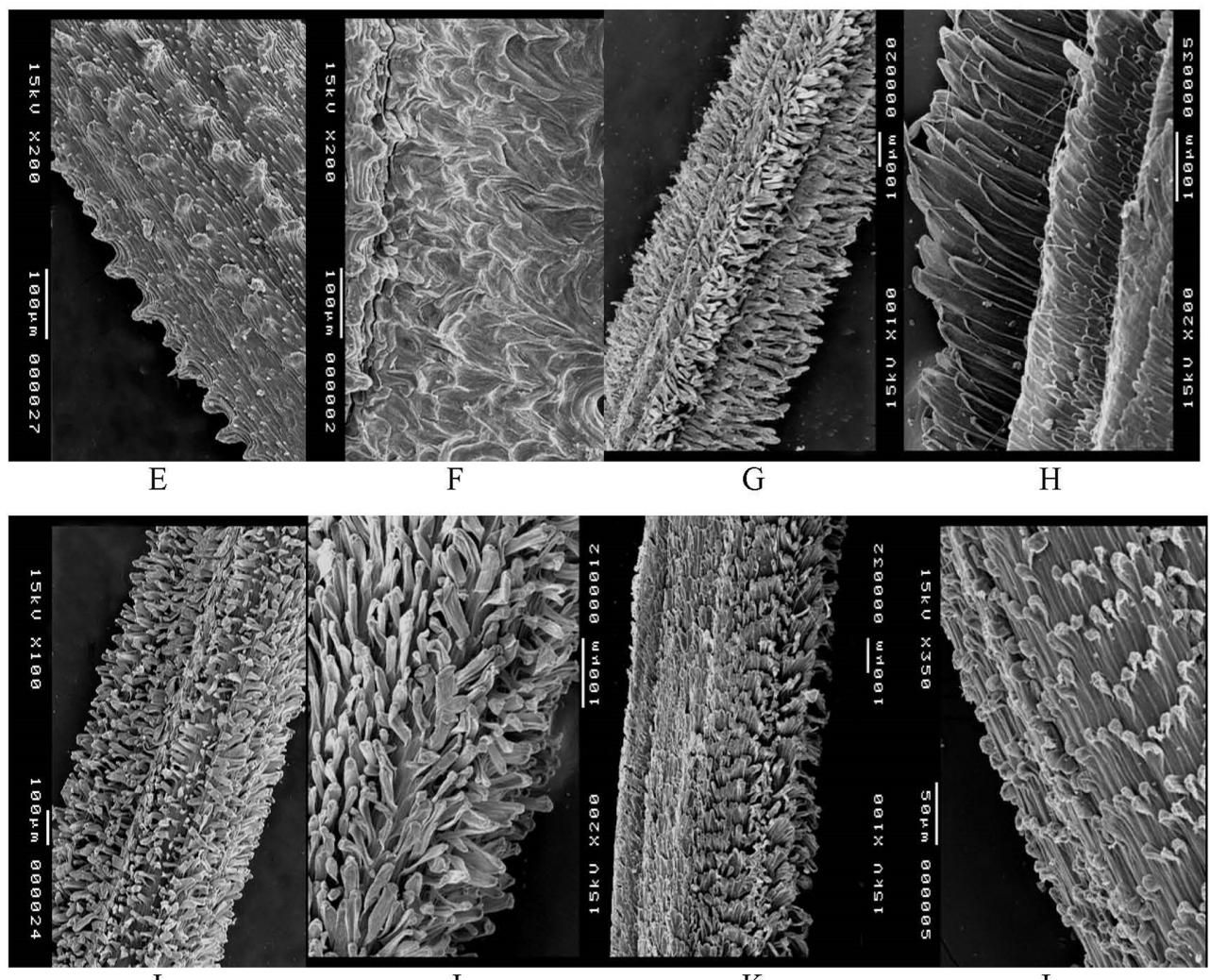

I

$\mathrm{K}$

$\mathrm{L}$

Fig. 3. Scanning elecron micrograph of marginal Launaea achenes surface. A. L. acanthodes. B. L. spinosa. C. L. nudicaulis. D. L. intybacea. E. L. massauensis. F. L. capitata. G. L. angustifolia subsp. angustifolia. H. L. angustifolia subsp. arabica. I. L. fragilis subsp. fragilis. J. L. fragilis subsp. tenuiloba. K. L. mucronata. L. L. cassiniana. 
species of sect. Zollikoferia (i.e., L. angustifolia, L. fragilis, $L$. mucronata and $L$. cassiniana), raised straight in $L$. spinosa, $L$. acanthodes, L. nudicaulis and L. capitata, and depressed straight in L. intybacea and L. massauensis, while the anticlinal boundaries of the inner achene are generally raised straight in all of the species except $L$. massauensis, being slightly sinuous margins. On the other hand, the periclinal walls are generally concave except for L. spinosa and L. acanthodes (Figs. 3, 4).
The pappus characters are much more useful for differentiation between some taxa; the setaceous type is only absent in $L$. angustifolia subsp. arabica, and the downy type is absent in four species (L. acanthodes, L. cassiniana, L. procumbens and $L$. capitata), with the pappus of the two later species having a pappus disk. Additionally, the pappus is persistent at the achene apex in all species except for L. procumbens, L. capitata and $L$. cassiniana, which are deciduous.

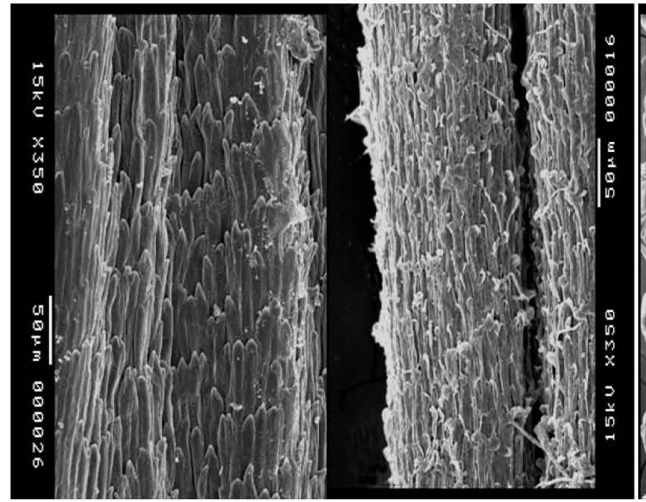

A

B

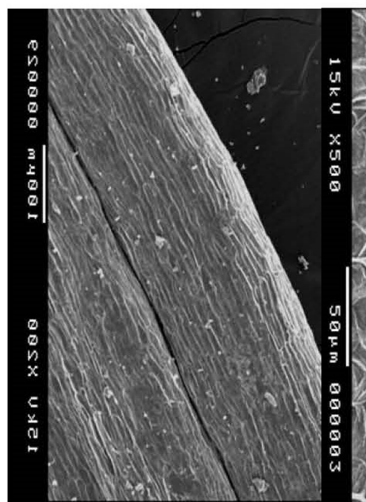

E

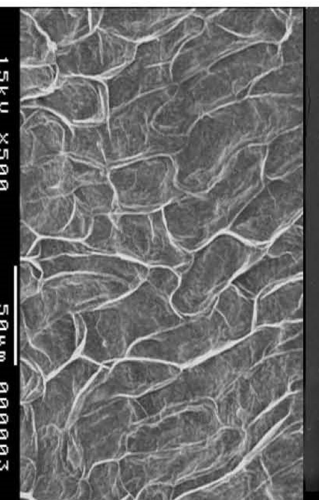

F

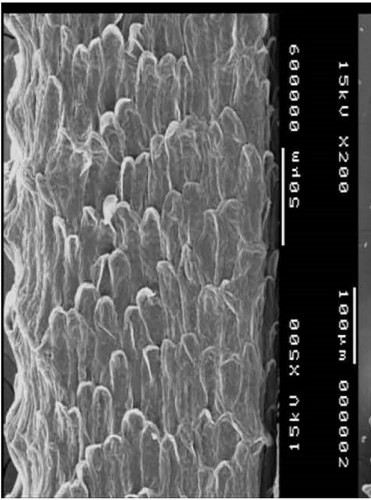

C

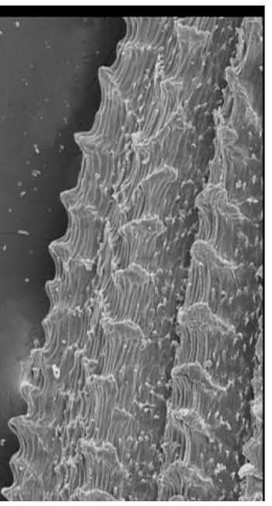

$\mathrm{D}$

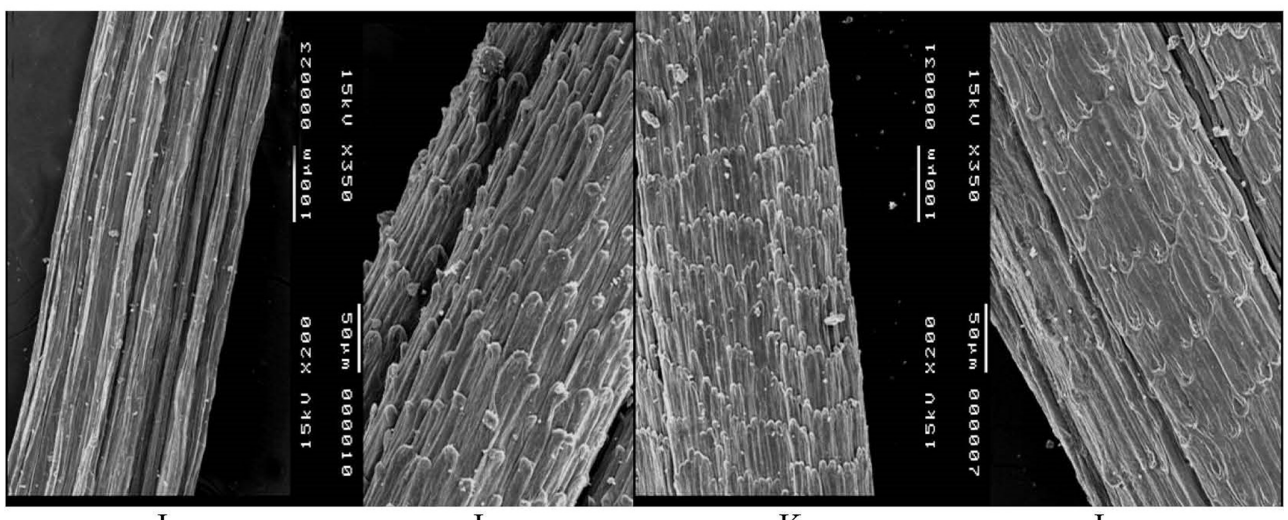

I

$\mathrm{J}$

$\mathrm{K}$

$\mathrm{L}$

Fig. 4. Scanning electron micrograph of inner Launaea achenes surface. A. L. acanthodes. B. L. spinosa. C. L. nudicaulis. D. L. intybacea. E. L. massauensis. F. L. capitata. G. L.angustifolia subsp. angustifolia. H. L. angustifolia subsp. arabica. I. L. fragilis subsp. fragilis. J. L. fragilis subsp. tenuiloba. K. L. mucronata. L. L. cassiniana. 
Table 3. Anatomical features of Launaea achenes.

\begin{tabular}{|c|c|c|c|c|c|c|c|c|c|c|c|c|c|c|}
\hline \multirow{3}{*}{ Taxon } & \multirow{3}{*}{ Pericarp } & \multirow{3}{*}{$\begin{array}{l}\text { Additional } \\
\text { strand }\end{array}$} & \multicolumn{6}{|c|}{ Marginal achenes } & \multicolumn{6}{|c|}{ Inner achenes } \\
\hline & & & \multicolumn{2}{|c|}{ Number } & \multicolumn{2}{|c|}{ Main costa } & \multicolumn{2}{|c|}{$\begin{array}{l}\text { Secondary } \\
\text { costa }\end{array}$} & \multicolumn{2}{|c|}{ Number } & \multicolumn{2}{|c|}{ Main costa } & \multicolumn{2}{|c|}{$\begin{array}{l}\text { Secondary } \\
\text { costa }\end{array}$} \\
\hline & & & $\begin{array}{l}\text { Main S } \\
\text { costa }\end{array}$ & $\begin{array}{l}\text { econdary } \\
\text { costa }\end{array}$ & Paren. & Scler. I & Paren. & Scler. & $\begin{array}{l}\text { Main } \\
\text { costa }\end{array}$ & $\begin{array}{l}\text { econdary } \\
\text { costa }\end{array}$ & Paren. & Scler. & Paren. & Scler. \\
\hline L. spinosa & $\begin{array}{l}\text { thick, laterally } \\
\text { compressed }\end{array}$ & absent & 5 & 10 & $2-5$ & $8-12$ & $4-6$ & $4-6$ & 4 & 8 & $2-5$ & $8-12$ & $4-6$ & $4-6$ \\
\hline L. nudicaulis & $\begin{array}{l}\text { thick, weakly } \\
\text { compressed }\end{array}$ & present & 5 & 10 & $2-5$ & $8-12$ & $4-6$ & $4-6$ & 4 & 8 & $10-15$ & $3-5$ & $4-6$ & $4-6$ \\
\hline L. intybacea & $\begin{array}{l}\text { thick, weakly } \\
\text { compressed }\end{array}$ & present & 5 & 10 & $2-5$ & $8-12$ & $4-6$ & $4-6$ & 4 & 8 & $10-15$ & $3-5$ & $4-6$ & $4-6$ \\
\hline L. massauensis & thick, compressed & present & 5 & 10 & $4-8$ & $7-12$ & $5-7$ & $3-6$ & 4 & 8 & $12-18$ & $4-8$ & $10-12$ & $3-6$ \\
\hline L. capitata & $\begin{array}{l}\text { very thick, } \\
\text { compressed }\end{array}$ & present & 5 & 10 & $20-25$ & $7-10$ & $7-12$ & $4-7$ & 4 & 8 & $25-30$ & $7-12$ & $15-20$ & $6-10$ \\
\hline $\begin{array}{l}\text { L. angustifolia subsp. } \\
\text { angustifolia }\end{array}$ & $\begin{array}{l}\text { very thick, } \\
\text { not compressed }\end{array}$ & absent & 5 & 10 & $2-5$ & $12-18$ & $4-6$ & $6-8$ & 4 & 8 & $2-5$ & $12-18$ & $3-5$ & $5-7$ \\
\hline $\begin{array}{l}\text { L. angustifolia subsp. } \\
\text { arabica }\end{array}$ & $\begin{array}{l}\text { thick, } \\
\text { not compressed }\end{array}$ & absent & - & - & - & - & - & - & 4 & 8 & $3-6$ & $10-18$ & $3-6$ & $5-8$ \\
\hline $\begin{array}{l}\text { L. fragilis subsp. } \\
\text { fragilis }\end{array}$ & $\begin{array}{l}\text { thick, } \\
\text { not compressed }\end{array}$ & absent & 5 & 10 & $4-8$ & $7-12$ & $5-7$ & $5-10$ & - & - & - & - & - & - \\
\hline $\begin{array}{l}\text { L. fragilis subsp. } \\
\text { tenuiloba }\end{array}$ & $\begin{array}{l}\text { very thick, weakly } \\
\text { compressed }\end{array}$ & absent & 5 & 10 & $9-11$ & $7-9$ & $3-6$ & $4-7$ & 4 & 8 & $10-15$ & $7-9$ & $3-6$ & $4-7$ \\
\hline L. mucronata & $\begin{array}{l}\text { thick, weakly } \\
\text { compressed }\end{array}$ & absent & 5 & 10 & $3-5$ & $6-9$ & $4-7$ & $5-7$ & 4 & 8 & $6-9$ & $4-7$ & $6-9$ & $3-5$ \\
\hline L. cassiniana & $\begin{array}{l}\text { thick, weakly } \\
\text { compressed }\end{array}$ & absent & 5 & 10 & $5-7$ & $7-11$ & $4-7$ & $6-10$ & 4 & 8 & $12-15$ & $7-11$ & $11-14$ & $6-10$ \\
\hline
\end{tabular}

The present investigation showed that the anatomical features of Launaea achenes are of minor taxonomic value. The presence of additional groups of sclerenchyma cells between the main and secondary costae proved to be useful and reliable for the distinction between the sections. In the studied species of sect. Microrhynchus (L. nudicaulis, $L$. intybacea and L. massauensis) and sect. Launaea (L. capitata), they are often present, whereas they are absent in the species of sect. Acanthosonchus and Zollikoferia, according to the study of Kilian (1997).

Kilian (1997) studied the anatomical features of L. intybacea and did not study L. massauensis. It is easy to differentiate anatomically between the two species on the basis of the difference between the main and secondary costa of the inner achenes; the first is characterized by separated and clearly differentiated costa while the latter is not differentiated. Thus, we follow Täckholm (1974) with regard to L. intybacea as conspecific. Furthermore, the anatomical characters can be used easily to distinguish certain taxa (Figs. 5, 6). L. capitata is characterized by 2-3 large, distinct wrinkled wings, and $L$. angustifolia subsp. arabica has a papillate wing. Nevertheless, the pericarp thickness of the inner achenes can be used to differentiate between the much closer species of $L$. mucronata and $L$. cassiniana; the first is composed of 9-16 parenchyma and sclerenchyma layers while the latter is much thicker and composed of 17-26 layers (Figs. 5, 6).

\section{Key to the taxa}

1. Marginal achenes pale yellow, broadly 2-3-winged …... L. capitata

1. Marginal achenes brownish to black, not winged (rarely

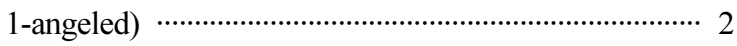

2. Marginal achenes surface wrinkled ……………….. 3

3. Achene subhomomorphic, main and secondary costae without additional groups of sclerenchyma cells between them ……………………………... 4

4. Achene apex truncate, with obscure secondary cell wall and antrose obtuse projections; pappus persistent …………………………. L. spinosa

4. Achene apex attenuate with fusiform secondary cell wall and triangular acute projections; pappus deciduous …………….. L. acanthodes 


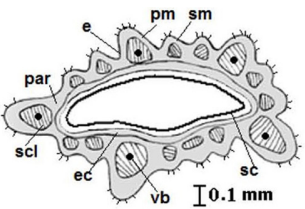

A

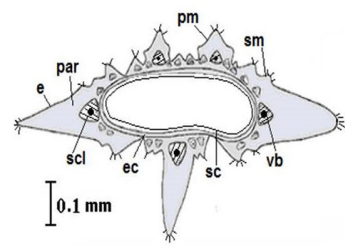

E

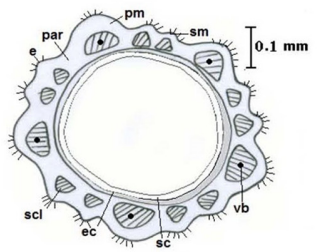

I

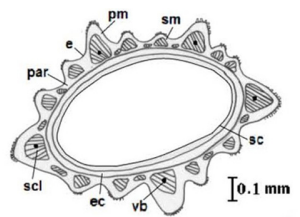

$\mathrm{B}$

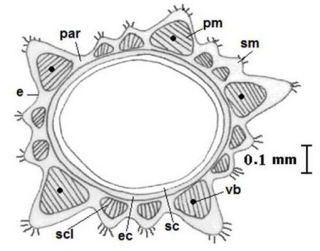

F

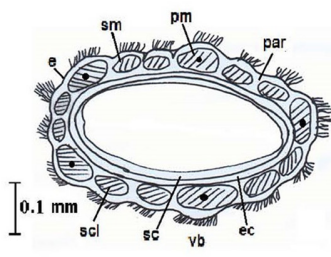

J

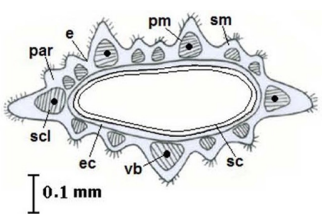

$\mathrm{C}$

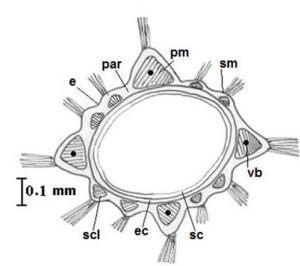

G

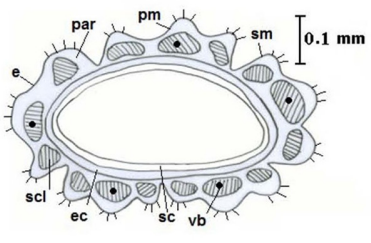

K

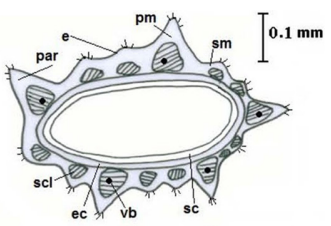

D

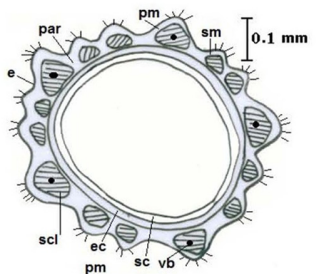

H

Fig. 5. Diagrammatic transverse section of marginal Launaea achenes. A. L. spinosa. B. L. nudicaulis. C. L. intybacea. D. L. massauensis. E. L. capitata. F. L. angustifolia subsp. angustifolia. G. L. angustifolia subsp. arabica. H. L. fragilis subsp. fragilis. I. L. fragilis subsp. tenuiloba. J. L. mucronata. K. L. cassiniana. e: epidermis, pm: primary mid rib, sm: secondary mid rib, par: parenchyma, scl: sclerenchyma, vb: vascular bundle, ec: endocarp, sc: seed coat.

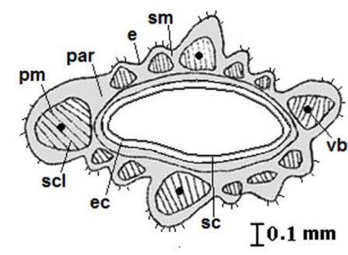

A

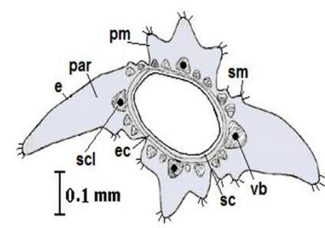

$\mathrm{E}$

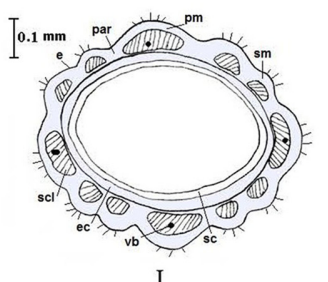

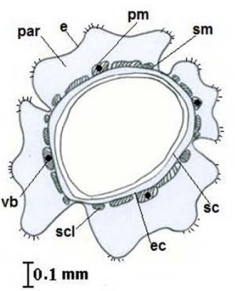

$\mathrm{B}$

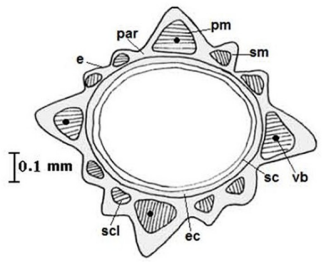

$\mathrm{F}$

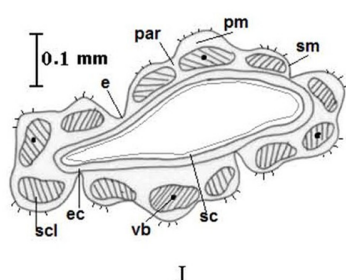

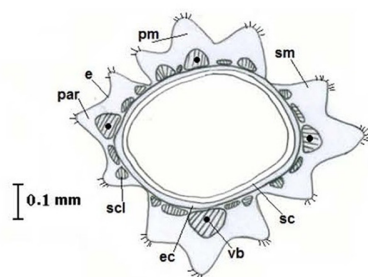

$\mathrm{C}$

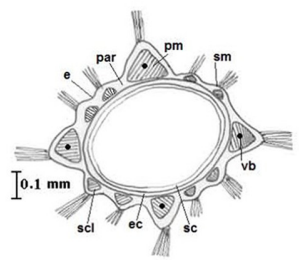

G

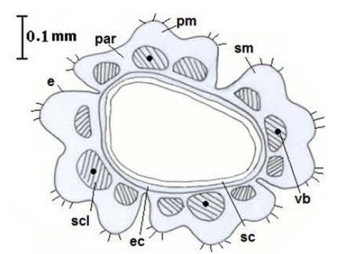

$\mathrm{K}$

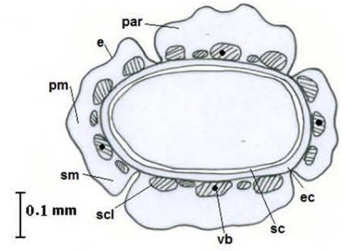

$\mathrm{D}$

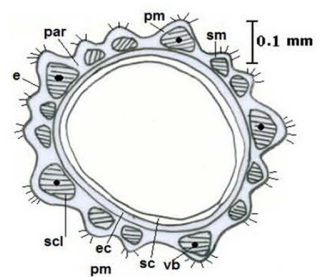

$\mathrm{H}$

Fig. 6. Diagrammatic transverse section of inner Launaea achenes. A. L. spinosa. B. L. nudicaulis. C. L. intybacea. D. L. massauensis. E. L. capitata. F. L. angusifolia subsp. angustifolia. G. L. angustifolia subsp. arabica. H. L. fragilis subsp. fragilis. I. L. fragilis subsp. tenuiloba. J. L. mucronata. K. L. cassiniana. e: epidermis, pm: primary mid rib, sm: secondary mid rib, par: parenchyma, scl: sclerenchyma, vb: vascular bundle, ec: endocarp, sc: seed coat. 
3. Achene heteromorphic, main and secondary costae with additional groups of sclerenchyma cells between them .... 5

5. Marginal achenes oblong, truncate, not beaked L. nudicaulis

5. Marginal achenes sub cylindrical, tapering or beaked

6. Marginal achenes brown, epidermal cells of inner achenes bone-shaped with depressed straight anticlinal walls …....... L. intybacea

6. Marginal achenes black, epidermal cells of inner achenes rectangular with raised straight to sinuous anticlinal walls $\cdots L$. massauensis

2. Marginal achenes surface papillose ………………... 7

7. Achenes 1-angled, marginal achenes silky, hirsute at angles, base 5-notched and with 5 projections $\cdots .8$

8. Inner achenes glabrous, marginal papillose; pappus dimorphic of setaceous and silky hairs

………....... L. angustifolia subsp. angustifolia

8. All achenes papillose; pappus monomorphic of silky hairs …… L. angustifolia subsp. arabica

7. Achenes cylindrical, not silky or hirsute, base truncate …....................................................... 9

9. Achenes longer than $6 \mathrm{~mm}$ long, innermost achenes 4-horned at base …………………... 10

10. Pappus as long as or slightly shorter than achene ………... L. fragilis subsp. fragilis

10. Pappus longer than the achene …………... ……….......... L. fragilis subsp. tenuiloba

9. Achenes shorter than $5 \mathrm{~mm}$ long, all achenes not horned at base ………………………………. 11

11. Pappus persistent, dimorphic; inner achenes with pericarp of 9-16 layers

L. mucronata

11. Pappus deciduous, monomorphic; inner achenes with pericarp of 17-26 layers .....

L. cassiniana

\section{Literature Cited}

Abid, R. D. and M. Qaiser. 2002. Cypsela morphology of Inula L. (s. str.) and its allied genera (Inuleae-Compositae) from Pakistan and Kashmir. Pakistan Journal of Botany 34: 207-223.

Abid, R. D. and M. Qaiser. 2008. Cypsela morphology of some genera in the tribe Gnaphalieae (Asteraceae) from Pakistan. Pakistan Journal of Botany 40: 473-485.

Amin, A. 1957. Taxonomic studies in the genus Launaea. M. Sc. Thesis, Botany Department, Faculty of Science, Cairo Uni- versity, Egypt.

Barthlott, W. 1981. Epidermal and seed surface characters of plants: systematic applicability and some evolutionary aspects. Nordic Journal of Botany 1: 345-355.

Blanca, G. and C. Guardia. 1997. Fruit morphology in Tragopogon L. (Compositae: Lactuceae) from the Iberian Peninsula. Botanical Journal of the Linnean Society 125: 319-329.

Boesewinkel, F. D. and F. Bouman. 1984. The Seed: Structure. In Embryology of Angiosperms. Johri, B. (ed.), Springer Berlin Heidelberg, Berlin Pp. 567-610.

Boissier, E. 1875. Flora Orientalis. Reg. Acad. Scient., Geneve and Basel.

Briquet, J. 1916. Études carpologiques sur les genres de Composées Anthemis, Ormenis et Santolina suivies de quelques conclusions anatomiques et physiologiques d'intérèt général. Annuaire du Conservatoire et du Jardin Botaniques de Genève 18-19 (IX): 257-313.

Briquet, J. 1930. Carpologie du genre Crupina. Candollea 4: 241278.

De la Guardia, C. D. and G. Blanca. 1987. Revisión del género Scorzonera L. (Compositae, Lactuceae) en la Península ibérica. Anales del Jardín Botánico de Madrid 43: 271-354.

Dittrich, M. 1968. Karpologische Untersuchungen zur Systematik von Centaurea un verwandten Gattungen. Botanischer Jahrbücher für Systematik 88: 70-122.

Dittrich, M. 1996. Die bedeutung morphologischer und anatomischer Achänen-Merkmale für die Systematik der tribus Echinopeae Cass. und Carlineae Cass. Boissiera 51: 9-102.

Esau, K. 1977. Anatomy of Seed Plants. John Wiley \& Sons.

Forsskål, P. and C. Niebuhr. 1775. Flora Aegyptiaco-arabica. Copenhagen.

Grau, J. 1980. Die Testa der Mutisieae und ihre systematische Bedeutung. Mitteilungen der Botanischen Staatssammlung München 16: 269-332.

Haque, M. and M. Godward. 1984. New records of the carpopodium in Compositae and its taxonomic use. Botanical Journal of the Linnean Society 89: 321-340.

Jan, B. K. and S. K. Mukherjee. 2012. Diversity of cypselar features of seven species of the genus Crepis L. in Compositae. Indian Journal of Fundamental and Applied Life Sciences 2: $51-58$.

Jan, B. K. and S. K. Mukherjee. 2013. Cypselar diversity of some species of the tribe Lactuceae (Compositae). Journal of the Botanical Society of Bengal 67: 51-61.

Johansen, D. A. 1940. Plant microtechnique. 1. New York Book Company, New York.

Kaul, V. and D. Singh. 1982. Embryology and development of fruit in Cichorieae. Lactuca Linn. Acta Biologica Cracovien- 
sia Series Botanica 24: 19-30.

Kilian, N. 1997. Revision of Launaea Cass. (Compositae, Lactuceae, Sonchinae). Englera 17: 1-478.

Lavialle, P. 1912. Recherches sur le développement de l'ovaire en fruit chez les Composées.

Mateu, I. and J. Guemes. 1993. Estudio carpologico del genero Launaea Cass. (Asteraceae) en europa. Boletim da Sociedade Broteriana 66: 85-95.

Merxmuller, H. and J. Grau. 1977. Fruchtanatomische Untersuchungen in der Inula-Gruppe (Asteraceae). Publication of Cairo University Herbarium 7: 9-20.

Mouradian, L. G. 1995. Comparative morpho-anatomical investigation of the achenes of Filifolium Kitam. and related genera. In Advances in Compositae systematics. Hind, D. J. N., C. Jeffrey and G. V. Pope (eds.), The Royal Botanic Gardens, Kew. Pp. 41-49.

Muschler, R. C. 1912. A Manual Flora of Egypt. Berlin, Berlin.

Ownbey, M. 1950. Natural hybridization and amphiploidy in the genus Tragopogon. American Journal of Botany 37: 487-499.

Pak, J. H., Park J. K. and S. S. Whang. 2001. Systematic implications of fruit wall anatomy and surface sculpturing of Microseris (Asteraceae, Lactuceae) and relatives. International Journal of Plant Sciences 162: 209-220.

Richardson, I. B. K. 1976. Tragopogon. In Flora Europaea. Turin, T., V. Heywood, N. Burges, D. Moore, D. Valentine, S. Waiters and D. Webb. (eds.), Cambridge University Press, Cambridge.
Stant, M. T. 1973. The role of the scanning electron microscope in plant. Kew Bulletin 28: 105-115.

Stearn, W. T. 1966. Botanical Latin. Nelson, T. \& Sons Lid, London, Edinburgh., London, Edinburgh.

Stebbins, G. L. 1953. A new classification of the tribe Cichorieae, family Compositae. Madrono 12: 65-81.

Täckholm, V. 1974. Students' Flora of Egypt. Cairo University, Egypt, Egypt.

Tomb, A. S. 1977. Lactuceae systematic review. In The Biology and Chemistry of the Compositae. Heywood, V. H., J. B. Harborne and B. L. Turner (eds.), London, Academic Press, New York, San Francisco. Pp. 1-7.

Wagenitz, G. 1976. Systematics and phylogeny of the Compositae (Asteraceae). Plant Systematics and Evolution 125: 29-46.

Zareh, M., A. Faried and M. Mohamed. 2016. Revision of Launaea Cass. (Compositae) in Egypt with special references to cypselar diversity. Feddes Repertorium 127: 1-16.

Zareh, M. M. 2005. Synopsis of the family Asteraceae in Egypt. International Journal of Agriculture and Biology 5: 832-844.

Zareh, M. M. 1987. Taxonomic and Achene Anatomy of Species of Anthemideae (Asteraceae) in Egyptý. Botany. Assiut University, Egypt.

Zhu, S. X., H. N. Qin and C. Shih. 2006. Achene wall anatomy and surface sculpturing of Lactuca L. and related genera (Compositae: Lactuceae) with notes on their systematic significance. Journal of Integrative Plant Biology 48: 390-399. 